\title{
Exploring Evaluation Factors and Framework for the Object of Automated Trading System
}

\author{
Danya Huang \\ University of International \\ Business and Economics \\ Beijing, China \\ ayayahuang@126.com
}

\author{
Xusen Cheng \\ University of International \\ Business and Economics \\ Beijing, China \\ xusen.cheng@uibe.edu.cn
}

\author{
Tingting Hou \\ University of International \\ Business and Economics \\ Beijing, China \\ htt0207@163.com
}

\author{
Kun Liu \\ University of International Business and Economics \\ Beijing, China \\ saraLiukun@163.com
}

\author{
Chengyao Li \\ University of International Business and Economics \\ Beijing, China \\ lcy2306@163.com
}

\begin{abstract}
Automated trading system (ATS) is a computer program that combines different trading rules to find optimal trading opportunities. The objects of ATS, which are financial assets, need evaluation because that is of great significance for stakeholders and market orders. From the perspectives of dealers, agents, external environment, and objects themselves, this study explored factors in evaluating and choosing the object of ATS. Based on design science research (DSR), we presented a preliminary evaluation framework and conducted semi-structured interviews with twelve trading participants engaged in different occupations. By analyzing the data collected, we validated eight factors from literatures and found four new factors and fifty-four sub-factors. Additionally, this paper developed a relationship model of factors. The results could be used in future work to explore and validate more evaluation factors by using data mining.
\end{abstract}

\section{Introduction}

During the development of smart city facilitated by information and communication technology (ICT), automated control processes with less human intervention have been established. It is involved in the fields of finance, transportation, medical treatment and environment, etc. [1]. Via application of machine learning algorithms, automated trading system (ATS), which is closely related to residents' lives based on smart city, leads to better trading performance significantly compared to the considered benchmarks [2]. With this system, different data sources are monitored, human traders are also notified of the trade at the optimal time [3]. The object of ATS refers to the target of the rights and obligations of the dealers, namely financial assets which need evaluation for protecting the interests of stakeholders. As a result, we tend to have a deeper understanding of the object of ATS.

The evaluation of automated trading has already been studied by quantities of researchers. However, rather than the evaluation of the object, previous researches focused more on the construction and evaluation of a specific trading system or a trading strategy. Lots of them focus on the study of evaluation to the effectiveness of an asset trading system [4]. Besides, several optimizing strategies of portfolios have been proposed and evaluated [5]. Some factors have been frequently used to evaluate automated trading strategies like risk and return. The market impacts are also supposed to be considered [6]. Evaluating and choosing an object requires a trade-off among various factors. Nevertheless, previous researches have paid little attention to the evaluation factors of the object of the system. Furthermore, with the acceleration of automation, it is necessary to develop a relationship model for the factors as the basis of evaluation index system which will help safeguard the interests of stakeholders. In an automated environment, the evaluation is also endowed with new features, varying from traditional one in financial markets which lack of intelligent characteristics [7]. Therefore, our study aims to explore evaluated factors for the object as the basis of evaluation index system.

The remainder of this paper is organized as follows: In this paper, Section 2 will provide the literature review, followed by research method in Section 3. In Section 4, data collection will be presented. Then we 
will analyze the results in Section 5 and have further discussion in Section 6. The final section will reveal the conclusion, limitation and put forward suggestions for future evaluation work.

\section{Background}

\subsection{Automated trading system (ATS)}

Along with the development of technologies and financial markets, the transaction method has gone through from the traditional method to on-line trading and to automated trading.

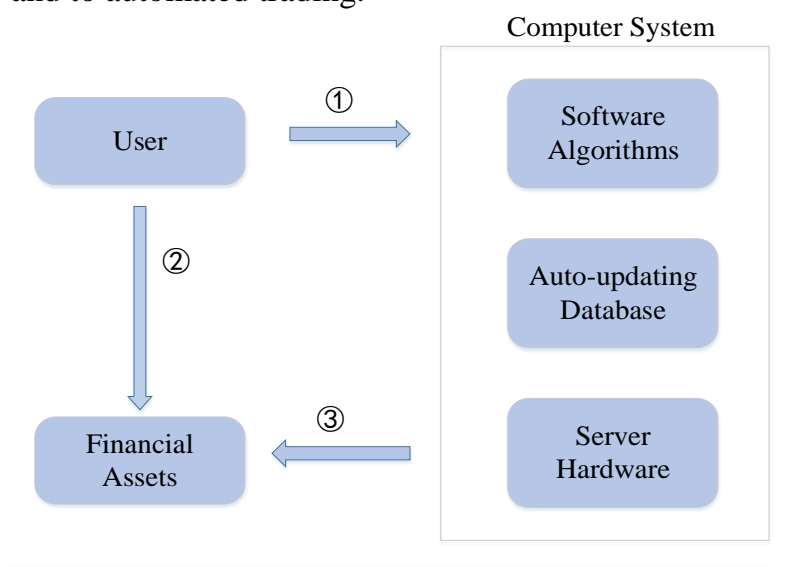

(1) Gathering and storing user information in the cloud (2)User's decision making

(3) Monitoring the market to find buying and selling opportunities

Figure 1. The process of automated trading

ATS, also referred to mechanical trading system or algorithmic trading system, provides a platform for traders to customize transaction rules according to specific requirements [6]. As is shown in Figure 1, through machine learning algorithms, the transaction process can be automatically executed via computers. The algorithm sets of rules are based on timing, price, quantity or any other mathematical model [2]. Many different technical indicators can be used to define entry and exit points. Some platforms provide intelligent guides to allow users to select and combine a set of rules with them for trades. Traders and investors can turn precise entry, exit and money management rules into the systems which allow computers to execute and monitor the trades. Once the rules are established, the computer will intelligently search for trading opportunities according to customer rules and algorithm trading strategies. It will also prepare to automatically generate the order that minimizes the loss [8].

The method for automated trading has been widely applied since early 1990s. Sorts of platform emerges such as Zulu Trade Platform, MetaTrader4, AvaTrade Aurotrader Platform, etc. Based on ATS, many researchers have presented stock prediction models. For example, a stock prediction model, which based on Evolutionary computation (EC), is able to use three analytical method categories involving fundamental analysis, technical analysis, and blending analysis [9]. The application of prediction models can help to find explicit trading rules.

ATS eliminates transaction barriers in traditional markets [3] and reduces the cost of establishing a new trading system, thus making it easier for new entrants to enter the market. At the same time, market data can be transmitted quickly. In addition, the number of participants will increase, which also promotes the development of trade.

\subsection{The object of ATS}

The object of ATS is the target of the rights and obligations of the dealer, namely financial assets. Financial assets is a general term for all financial instruments that can be traded in organized financial markets, with realistic prices and future valuation. [10]. Financial assets involve cash, equity instruments of another equity, a contractual right to receive a financial asset from another entity, a contractual right to exchange financial assets or liabilities. In addition to stocks and receivables, the above definition comprises financial derivatives, bonds, deposits and equity stakes [11]. Furthermore, in order to ensure a certain level of profit and to minimize the risk, these financial assets need to be matched reasonably [12]. Portfolios refer to the proper matching of all kinds of stocks, bonds, cash and real estate. Through scientific analysis and evaluation, it can help to achieve better performance.

\subsection{Evaluation factors}

2.3.1. Evaluation factors for general products. Though there are various products, they can be classified into different categories according to their characteristics. In this case people establish a set of assessments to determine which product from the same category is better worth buying. The completeness and comprehensiveness of the set of assessments will have a great impact on customers' buying behavior. In previous researches, the measure of product performance level success, firm level success and customer level success are recommended for the assessment of products [13]. In other word, when evaluating and choosing general product, factors related to customers, products and firms need to be considered at least. 
2.3.2. Evaluation factors for financial assets. When evaluating financial assets, risk and return are considered as fundamental evaluation factors. They are related to the objects of financial trading and usually used for decision making in stock or bond trading. However, according to Fama et al. [14], the evaluation of the object is based on different kinds of variables including maturity, default risks, firm size, book-tomarket equity, and an overall market factor. Therefore, apart from factors of the three aspects mentioned in the part of general products, the external environment factors should also be taken into account when evaluating or selecting financial assets. For example, the framework, which put forward by Cadoni et al. [15] for evaluating the risk level of pension fund portfolios, is based on market indexes.

2.3.3. Evaluation factors for the object of ATS. As we mentioned above, the objects of ATS are financial assets which are special products. Considering evaluation factors for general products and financial instruments, we need to focus on four aspects including customers, products, firms and the external environment. What can't be ignored is that the stakeholders vary in different industries. Therefore, together with the particularity of stakeholders in automated trading, aspects related to dealers, objects of transaction, automated trading agents, external environment relatively, need to be taken into account accordingly. The dealers can be all the owners of assets, including individuals and financial institutions such as banks, the stock exchange financial institutions, trust and investment companies, etc. [16]. The automated trading agents are operating companies of ATS. Additionally, the external environment factors which are macro-variables involving macroeconomic environment, economic construction level and social level [15]. After exploring the scope of the impact factors of the objects, we attempted to excavate main factors based on the four aspects. By searching references in previous research, we finally extracted the following factors:

Trust could be considered as a dealer factor. Trust or corporate trust is a large group of business interests with significant market power, which may be embodied as a corporation or as a group of corporations that cooperate with one another in various ways. Trust is identified as one of the key factors when people trade with each other [17]. One will never buy a product without trusting its quality. Moreover, trust plays a crucial role in technology adoption [18].

Technology, which is an automated trading agent factor, has penetrated throughout all sorts of industries including trading [19]. Advanced technology can improve firm performance to a great extent. Plus, firms can also improve their products' quality to get higher profits by developing technologies.

Reputation, an automated trading agent factor, plays an important role especially in online trading. Information such as transactions' histories and previous customers' comments are offered to help users make decisions through their trust on the company or company's reputation [18] [20].

Risk is a factor related to the object of transaction. It exists everywhere and often coexists with benefits. Consumers measure risk and return to determine their purchasing behavior [21]. When people trade, they usually measure the relationship between risk and return. Some people will take high risk for high returns, while others will accept low benefits in order to avoid risks. In general, people will determine their trading behavior according to their perceptions of risks and returns [5] [22].

Market mechanism could be regarded as an external environment factor. The market mechanism is a way of accumulating supply and demand for participants and determining a price in the market [6]. Costumers will change their purchasing behaviors when market mechanism changes [23].

Regulation could be considered as an external environment factor. The government will play a regulatory role in the financial sector, which will help to maintain healthy social transactions [24] [25].

Network externalities, as an external environment factor, refers to the phenomenon that value of a product increases with a large installed base of users [26]. With the development of technology, network externalities also show impact on the object of ATS [27] [28].

\section{Methods}

Considering the approach used in other similar studies [29], design science research [30] was chosen as the research methodology. Design science research (DSR) method is a process of solving problems [31], which consists of 6 steps including problem recognition and incentive, target recognition, design, presentation, evaluation and communication feedback [32] [33]. In this field, researchers focus on specific problems and provide feasible solutions to the problem. [34]. When DSR is used for research, from design to evaluation, it can always be combined with in-depth interview verification to draw a conclusion [35] [36].

According to the question talked about in this research, we need to establish a preliminary framework for object evaluation. The framework is supposed to be augmented and validated by data that collected. Then we also need to find out the relationship among factors 
that have been excavated in the process. The research idea is corresponded to previous researches. Thus, it is reasonable and applicable to choose a combination of DSR and in-depth interview method. In practice, we firstly used the DSR method to find some basic factors from literatures. Secondly, we conduct in-depth interviews for data collecting. The method of interview research is frequently used for collecting qualitative data. Based on the first level factors and the scope that are screened out from relevant literatures, we designed the outline of interview. Finally, twelve participants of automated trading were interviewed, and the data collected were transcribed, coded and analyzed.

\section{Data collection}

For the interview data, the code used was Ik (k refers to the numbers of different interviewees). These interviewees, who are all users of ATS and engaged in various industries, are between the age of 21 and 50 . They include: Bank practitioner (I1, I3, Female), Government employee (I2, Male), Internet practitioner (I4, I6, Male), Graduate student of accounting major (I5, Female), Professor of Finance and trade (I7, Female), Insurance Practitioner (I8, Male), Senior investor (19, I10, Male), Securities practitioner (I11, Female), Professor of Computer (I12, Male). During the interview, we focused on the dealer, the automated trading agent, the object of transaction, the external environment and the impact of the factors of these four aspects on the object of ATS. The data collected will show interviewees' opinions on what factors would influence object selection.

\section{Results}

\subsection{Eight evaluation factors}

The eight evaluation factors precipitated from the literature are validated in the semi-structure interview. Furthermore, in order to dig out sub-factors associated with factors existed in the available level, we analyzed the initial coding results of interview data using qualitative methods. In this section, we selected the critical statements and extracted keywords from them. Then, we classified the keywords for refining subfactors and drew conclusions. Our analysis results of each factor mentioned above are as follows.

Evidence of risk and its sub-factors are analyzed from interviewees and are listed in Table 1. A direct link between risk and profitability is existed in the automated environment. We find out six sub-factors which have been frequently indicated in the interview. Four of them are deeply associated with the system, especially for decision-making and asset operation which are influenced by data source, algorithm and so on.

Table 1. Comments example for risk

\begin{tabular}{|c|c|c|}
\hline & Sub-factor & Comments Example \\
\hline \multirow{6}{*}{ Risk } & $\begin{array}{l}\text { Liquidity } \\
\text { Risk }\end{array}$ & $\begin{array}{l}\text { [I6] I couldn't take too much financial } \\
\text { risk, so I bought short-term financial } \\
\text { products to avoid it. }\end{array}$ \\
\hline & Market Risk & [I3] The market is unpredictable. \\
\hline & $\begin{array}{l}\text { Operational } \\
\text { Risk }\end{array}$ & $\begin{array}{l}\text { [I4] Whether the machine is trained } \\
\text { enough to make it a mature product is a } \\
\text { significant factor to measure whether it } \\
\text { can be put into use. }\end{array}$ \\
\hline & $\begin{array}{l}\text { The Risk of } \\
\text { Decision } \\
\text { Making }\end{array}$ & $\begin{array}{l}\text { [I4] Most people will choose the funds } \\
\text { moderately profitable, and then take on } \\
\text { the risks that they can hold. The } \\
\text { standard varies from person to person. }\end{array}$ \\
\hline & Issuer Risk & $\begin{array}{l}\text { [I7] Whether the management of the } \\
\text { whole organization is standardized? All } \\
\text { of these involve high risks. }\end{array}$ \\
\hline & $\begin{array}{l}\text { Information } \\
\text { Security Risk }\end{array}$ & [I6] If the database leaks, it's all over. \\
\hline
\end{tabular}

Evidence of return and its sub-factors are analyzed from interviewees and are listed in Table 2. Traders are involved in the automated trading process for earning or hedging. As is mentioned by interviewees, since different objects are faced with different kinds of risk, the characteristics of an asset need to be considered in evaluation. Nevertheless, three other factors, as shown in Table 2, are also frequently mentioned. Particularly, there is an advantage of automated trading strategies in risk-matching and product recommendation, which may raise the expected rates of return.

Table 2. Comments example for return

\begin{tabular}{|l|l|l|}
\hline & Sub-factor & Comments Example \\
\hline \multirow{5}{*}{$\begin{array}{l}\text { Asset } \\
\text { Characteristic }\end{array}$} & $\begin{array}{l}\text { [I4] The higher the risk, the greater the } \\
\text { profit. [I3] It needs to be cashed in } \\
\text { time. }\end{array}$ \\
\cline { 2 - 3 } & $\begin{array}{l}\text { Historical } \\
\text { Performance }\end{array}$ & $\begin{array}{l}\text { [I2] I would consider its historical } \\
\text { evaluation. }\end{array}$ \\
\cline { 2 - 3 } & $\begin{array}{l}\text { Expected } \\
\text { Return }\end{array}$ & $\begin{array}{l}\text { [I3] Recommending products through } \\
\text { risk matching is a relatively safe way } \\
\text { of managing money. }\end{array}$ \\
\cline { 2 - 3 } & $\begin{array}{l}\text { Periodic } \\
\text { Income }\end{array}$ & $\begin{array}{l}\text { [I6] There are some financial products } \\
\text { that are profitable every day. }\end{array}$ \\
\hline
\end{tabular}

Evidence of technology and its sub-factors are analyzed from interviewees and are listed in Table 3. Technology brings big changes to evaluation methods, since it helps users to formulate their trading strategies, aimed at bringing about dividends. During our research, interviewees presented many technical factors that needed to be concerned from different perspectives, as shown in Table 3. Among them, questions related to 
data are indicated repeatedly, which is worthy of attention in future work.

Table 3. Comments example for technology

\begin{tabular}{|l|l|l|}
\hline & Sub-factor & Comments Example \\
\hline \multirow{7}{*}{ Technology } & $\begin{array}{l}\text { Acquisition } \\
\text { and } \\
\text { Processing }\end{array}$ & $\begin{array}{l}\text { [I12] The data services among } \\
\text { various agencies have gaps in } \\
\text { detail. Furthermore, there is also } \\
\text { a big gap in the algorithm details. }\end{array}$ \\
\cline { 2 - 3 } & $\begin{array}{l}\text { System } \\
\text { Maturity }\end{array}$ & $\begin{array}{l}\text { [I9] The accuracy and timeliness } \\
\text { of real-time transactions are very } \\
\text { important for the whole } \\
\text { transaction. }\end{array}$ \\
\cline { 2 - 4 } & $\begin{array}{l}\text { R\&D Team } \\
\text { Performance }\end{array}$ & $\begin{array}{l}\text { [I6] For example, there will be } \\
\text { more people willing to believe in } \\
\text { such a team like Google. }\end{array}$ \\
\cline { 2 - 4 } & $\begin{array}{l}\text { [I7] The government has } \\
\text { gradually suppressed illegal } \\
\text { institutions. In addition, the } \\
\text { platform should pay more } \\
\text { attention to the security of high- } \\
\text { tech and online funds. }\end{array}$ \\
\hline
\end{tabular}

Evidence of reputation and its sub-factors are analyzed from interviewees and are listed in Table 4. Reputation of agents is built through interactions with traders [18] in an automated environment, which is concerned to be one of the factors for product choosing. These factors will promote reputation. Trust is another filed influenced by these factors.

Table 4. Comments example for reputation

\begin{tabular}{|c|c|c|}
\hline & Sub-factor & Comments Example \\
\hline \multirow{6}{*}{ Reputation } & $\begin{array}{l}\text { Social } \\
\text { Capacity }\end{array}$ & $\begin{array}{l}\text { [I4] Public relation is also important } \\
\text { for goodwill. }\end{array}$ \\
\hline & $\begin{array}{l}\text { Word-of- } \\
\text { Mouth }\end{array}$ & $\begin{array}{l}\text { [I1] Reputation and word of mouth } \\
\text { influence trust. }\end{array}$ \\
\hline & $\begin{array}{l}\text { Long-Term } \\
\text { Brand } \\
\text { Effect }\end{array}$ & $\begin{array}{l}\text { [I5] I may still believe in things that } \\
\text { are tested by time. [I1] Old brands. }\end{array}$ \\
\hline & $\begin{array}{l}\text { Information } \\
\text { Disclosure }\end{array}$ & $\begin{array}{l}{[\text { I4] The information disclosed by }} \\
\text { good reputation companies is real } \\
\text { and effective. }\end{array}$ \\
\hline & Quality & $\begin{array}{l}\text { [I6] To enhance trust, the first thing } \\
\text { needed to do is to ensure the } \\
\text { product quality. }\end{array}$ \\
\hline & $\begin{array}{l}\text { Operating } \\
\text { Condition }\end{array}$ & $\begin{array}{l}\text { [I8] One of the factors that can be } \\
\text { raised is the time of company's } \\
\text { capital use. }\end{array}$ \\
\hline
\end{tabular}

Evidence of trust and its sub-factors are analyzed from interviewees and are listed in Table 5. Trust is a shared essential factor for the evaluation at each stage of trading process. We extracted key information and refined seven sub-factors. Some of them are cognitive sub-factors, while others are affective sub-factors. Furthermore, they will then have influence on the behavioral intention of traders [17]. It is worth mentioned that the cognition and emotion of interviewees are associated with technical factors. Most of interviewees mention that it is not technology itself but the benefits influenced by the development of technology that attract their attention.

Table 5. Comments example for trust

\begin{tabular}{|l|l|l|}
\hline \multirow{7}{*}{ Benefit } & $\begin{array}{l}\text { [I4] As a system, what do you have to } \\
\text { convince people? The answer must be } \\
\text { benefits. }\end{array}$ \\
\hline \multirow{5}{*}{ Convenience } & $\begin{array}{l}\text { [I2] Getting data should be automatic } \\
\text { rather than rigid. }\end{array}$ \\
\hline Trust & $\begin{array}{l}\text { [I2] Consumers are concerned about } \\
\text { Seur product. If the products you launch } \\
\text { Security } \\
\text { are not suitable for this market, you will } \\
\text { not be successful. } \\
{\left[\begin{array}{l}\text { [I7] They should pay more attention to } \\
\text { the security of high-tech and online } \\
\text { funds. }\end{array}\right.}\end{array}$ \\
\hline \multirow{2}{*}{ Dependency } & $\begin{array}{l}\text { [I6] If the time-effectiveness and } \\
\text { breadth of information are guaranteed, } \\
\text { more people will rely on this. }\end{array}$ \\
\hline Enjoyment & $\begin{array}{l}\text { [I6] There are some financial products } \\
\text { that are profitable every day. Customer } \\
\text { have fun with these cool products. }\end{array}$ \\
\hline Expectation & $\begin{array}{l}\text { [I4] If the product fails to achieve its } \\
\text { expected function, it is not a good } \\
\text { product. }\end{array}$ \\
\hline
\end{tabular}

Evidence of market mechanism and its sub-factors are analyzed from interviewees and are listed in Table 6. In this section, there are a few sub-factors which have been mentioned a lot by interviewees. Based on these sub-factors, the completeness of the market can be judged, thus affecting the evaluation of the tradable objects. In an efficient market, the information related to trading is quickly reflected in the market price, which has a great effect on the validity of the trader's decisions. In the intelligent environment, the interaction between market mechanism and market tools vary from the traditional trading market.

Table 6. Comments example for market mechanism

\begin{tabular}{|l|l|l|}
\hline & Sub-factor & Comments Example \\
\hline \multirow{4}{*}{$\begin{array}{l}\text { Market } \\
\text { Mechanism }\end{array}$} & \begin{tabular}{l} 
Market \\
Reaction \\
\cline { 2 - 3 }
\end{tabular} & $\begin{array}{l}\text { Maccording to the market feedback } \\
\text { or national policies. }\end{array}$ \\
\cline { 2 - 3 } & $\begin{array}{l}\text { [I4] Effective markets and these } \\
\text { market tools are mutually } \\
\text { reinforcing relationships. }\end{array}$ \\
\hline Market & $\begin{array}{l}\text { [I8] The main factors are whether } \\
\text { Recognition }\end{array}$ & $\begin{array}{l}\text { government recognizes the } \\
\text { participation of investors and the } \\
\text { degree of recognition. }\end{array}$ \\
\hline
\end{tabular}




\begin{tabular}{|l|l|l|}
\hline $\begin{array}{l}\text { Assets } \\
\text { Concentrati } \\
\text { on Level }\end{array}$ & $\begin{array}{l}{[\text { I6] Funds will be concentrated in }} \\
\text { the hands of a few people and } \\
\text { unfair situations will arise. }\end{array}$ \\
\hline
\end{tabular}

Evidence of regulation and its sub-factors are analyzed from interviewees and are listed in Table 7. When it comes to regulation, six main sub-factors are frequently mentioned. Trading is a profit-oriented behavior, so it must be regulated by government and its agencies at the same time. Thus, it is necessary to find a balance point between compliance and profitability. Meanwhile, agencies can effectively grasp more profitable opportunities, even obtaining official support by mastering the direction of policies and responding to them accurately. Aside from that, it is worth noting that whether the development of technology will affect fairness of trading, for some agencies dominating market share.

Table 7. Comments example for regulation

\begin{tabular}{|l|l|l|}
\hline & Sub-factor & Comments Example \\
\hline \multirow{7}{*}{ Regulation } & $\begin{array}{l}\text { Qualification } \\
\text { Authentication }\end{array}$ & $\begin{array}{l}{[\text { I2] Platforms, companies need to }} \\
\text { be endorsed by government } \\
\text { agencies. }\end{array}$ \\
\cline { 2 - 3 } & $\begin{array}{l}\text { The } \\
\text { Legitimacy of } \\
\text { Return }\end{array}$ & $\begin{array}{l}\text { I2] Sometimes, they can make a } \\
\text { profit only if they speculation } \\
\text { within the policy context. }\end{array}$ \\
\cline { 2 - 3 } & $\begin{array}{l}\text { Product } \\
\text { [I8] It's a very strict investigation. } \\
\text { For example, one-click following } \\
\text { up is not allowed before. }\end{array}$ \\
\cline { 2 - 3 } & $\begin{array}{l}\text { Oligarchic } \\
\text { Tendencies } \\
\text { willing to use your products which } \\
\text { are probably things affect market } \\
\text { fairness. }\end{array}$ \\
\cline { 2 - 3 } & $\begin{array}{l}\text { [I5] Response national policies and } \\
\text { the country will give you a lot of } \\
\text { discounts which can help to } \\
\text { promote company values. }\end{array}$ \\
\hline
\end{tabular}

Evidence of network externalities and its subfactors are analyzed from interviewees and are listed in Table 8. According to the data from interview transcripts, we find three frequent-indicated sub-factors. As more people get involved in automated trading, functions of the systems can be developed for more profits, existing problems can easily be found and solved, too. In addition, the increase of capital will push up the stock price. Investors expect for an active market, but once price varies greatly, the risk will become sharp, which will affect market orders as well as the product. The whole process is based on customer involvement.

\section{Table 8. Comments example for network} externalities

Sub-factor Comments Example

\begin{tabular}{|l|l|l|}
\hline \multirow{4}{*}{$\begin{array}{l}\text { Network } \\
\text { Externalities }\end{array}$} & $\begin{array}{l}{[\text { I3] The price can be higher if }} \\
\text { there was more money. } \\
\text { [I10] The value should be } \\
\text { determined by its own stock } \\
\text { price. }\end{array}$ \\
\cline { 2 - 3 } & $\begin{array}{l}\text { Functional } \\
\text { Development }\end{array}$ & $\begin{array}{l}\text { [I4It will function when more } \\
\text { people use it. [I6] It is necessary } \\
\text { for your server to keep stable. }\end{array}$ \\
\cline { 2 - 3 } & $\begin{array}{l}\text { Customer } \\
\text { Involvement }\end{array}$ & $\begin{array}{l}\text { [I9] Automated trading platform } \\
\text { can be influenced by the } \\
\text { involvement of customer. }\end{array}$ \\
\hline
\end{tabular}

\subsection{New factors and sub-factors}

In this section, we excavate four new factors and their sub-factors according to the in-depth interview.

Evidence of cost and its sub-factors are analyzed from interviewees and are listed in Table 9. According to Geva et al. [4], transaction cost refers to cost of buying and selling stocks. However, in our research, apart from transaction cost, interviewees present another kind of cost, production costs [33], specifically, R\&D costs, to better evaluate the object. From traders' perspective, the amount of transaction cost can influence their purchasing decision. While from agents' standpoint, the existence of R\&D costs may impact on technology research and development directly.

Table 9. Comments example for cost

\begin{tabular}{|l|l|l|}
\hline & Sub-factor & Comments Example \\
\hline \multirow{4}{*}{ Cost } & R\&D Costs & $\begin{array}{l}\text { [I12] If there is no benefit, there is no } \\
\text { motivation to upgrade this intelligent } \\
\text { system. }\end{array}$ \\
\cline { 2 - 3 } & $\begin{array}{l}\text { Transaction } \\
\text { Cost }\end{array}$ & $\begin{array}{l}\text { [I1] It is not very bad if you invest little, } \\
\text { if not, they will charge for a large } \\
\text { amount of transaction fee. }\end{array}$ \\
\hline
\end{tabular}

Evidence of software design and its sub-factors are analyzed from interviewees and are listed in Table 10. Software is a carrier of publish/subscribe communication [8] in ATS. During the interview, statements associated with software design are indicated frequently as well. Furthermore, four main sub-factors are in relation to this first level factor. Problems with complexity are highly regarded, both in software operation, and in interface design. Additionally, low-quality content, such as comments from non-professional users, could affect the customer experience negatively.

Table 10. Comments example for software design

\begin{tabular}{|l|l|l|}
\hline & Sub-factor & Comments Example \\
\hline $\begin{array}{l}\text { Software } \\
\text { Design }\end{array}$ & $\begin{array}{l}\text { Information } \\
\text { Quality }\end{array}$ & $\begin{array}{l}\text { [I1] I would rather not to see them } \\
\text { if the information quality of the }\end{array}$ \\
\hline
\end{tabular}




\begin{tabular}{|l|l|l|}
\hline & user evaluation is not good. \\
\cline { 2 - 3 } $\begin{array}{l}\text { Interface } \\
\text { Designs }\end{array}$ & $\begin{array}{l}\text { [I6] The interface design is too } \\
\text { complicated. }\end{array}$ \\
\cline { 2 - 3 } $\begin{array}{l}\text { Operation } \\
\text { Complexity }\end{array}$ & $\begin{array}{l}{[\mathrm{I} 6] \text { How to tell investors what }} \\
\text { your financial product are and how } \\
\text { to operate in a simple way? }\end{array}$ \\
\cline { 2 - 3 } & $\begin{array}{l}\text { [I6] How to involve them into this } \\
\text { platform and to make them more } \\
\text { likely to see your products? You } \\
\text { Friendliness } \\
\text { should design a process like the } \\
\text { notice task in the game. }\end{array}$ \\
\hline
\end{tabular}

Evidence of marketing and its sub-factors are analyzed from interviewees and are listed in Table 11. Marketing is supposed to be taken into consideration when talking about financial markets [38]. According to the data analysis of transcripts, five sub-factors are related to marketing. In an automated environment, we should also pay more attention to previous marketing tactics. Meanwhile, artificial intelligence will bring product introductions and diversification more opportunities. Furthermore, it focuses on personalization and customization. According to interviewees, those aspects related to changes of marketing tactics driven by innovation are note-worthy for evaluation.

Table 11. Comments example for marketing

\begin{tabular}{|l|l|l|}
\hline & Sub-factor & Comments Example \\
\hline \multirow{5}{*}{ Marketing } & $\begin{array}{l}\text { [I1] There is minimum } \\
\text { investment for many products. } \\
\text { But probably, I don't have } \\
\text { much money that time. }\end{array}$ \\
\cline { 2 - 3 } & $\begin{array}{l}\text { The Product } \\
\text { Diversification }\end{array}$ & $\begin{array}{l}\text { [I2] There are so much } \\
\text { financial products. In addition, } \\
\text { they need to be classified by } \\
\text { different level. }\end{array}$ \\
\cline { 2 - 3 } & $\begin{array}{l}\text { Product } \\
\text { Introductions } \\
\text { this platform to involve them into } \\
\text { more likely to see your } \\
\text { products? }\end{array}$ \\
\cline { 2 - 3 } & Promotion & $\begin{array}{l}\text { [I1] There are some discounts } \\
\text { if you log in. }\end{array}$ \\
\cline { 2 - 3 } Branding & $\begin{array}{l}\text { [I2] First, the image of the } \\
\text { product and your brand is } \\
\text { primary concern. }\end{array}$ \\
\hline
\end{tabular}

Evidence of service and its sub-factors are analyzed from interviewees and are listed in Table 12. Service problems should also be considered for the evaluation [37]. According to the data analysis of transcripts, four sub-factors are frequently noted. In automated trading process, customers have little awareness on the application of the platform technology. In addition, it can be a question for a virtual product to perfect the after service. Those aspects will lead to different performances of agents, which are concerns in evaluation process.

\section{Table 12. Comments example for service}

\begin{tabular}{|l|l|l|}
\hline & Sub-factor & Comments Example \\
\hline \multirow{4}{*}{ Service } & Communication & $\begin{array}{l}\text { [I2] I need communication and } \\
\text { after service. [I8] It is necessary to } \\
\text { make investors understand the } \\
\text { operation and profit status of } \\
\text { agents. }\end{array}$ \\
\cline { 2 - 3 } & After Service & $\begin{array}{l}\text { [I2] There can be some regular } \\
\text { return visits. }\end{array}$ \\
\cline { 2 - 3 } & Punctuality & $\begin{array}{l}\text { [I2] Keep your word and offer } \\
\text { return to investors on time. }\end{array}$ \\
\cline { 2 - 3 } & $\begin{array}{l}\text { Service } \\
\text { Duration }\end{array}$ & $\begin{array}{l}\text { [I2] You need to provide } \\
\text { continuous service, instead of } \\
\text { forgetting your users once they } \\
\text { invest product. }\end{array}$ \\
\hline
\end{tabular}

\section{Discussion}

According to the data collected, new evaluation factors for the object of ATS can also be parts of the four aspects we mentioned above, corresponding to traditional trading. There is also something different between factors of automated trading and traditional ones. Especially for sub-factors, rather than financial index, they are more relevant to intelligent characteristics.

Apart from questions based on the factors, the interviewees talked a lot in the part of open questions. By analyzing the data, we found that, in addition to sub-factors associated with new main factors, interviewees also presented their potential relationships with previous points. Furthermore, there are possible causal relationships between these factors. In this part, the high frequency factors include service, communication, cost, transaction cost, marketing and the product diversification which are new factors and their sub-factors. Some factors from literatures and their sub-factors were also indicated frequently. They are technology, technology compliance, return, and periodic income. In addition, from the part of the factors-based questions, we can find the linkages among other factors indicated by interviewees. In Figure 2, we integrated these elemental observations showing the linkages based on the same dimension or different ones. Specifically, as we presented in section 2 , we classified the whole factors into four aspects. Cost, return and risk are objects of transaction factors. Service, marketing, technology, software design and reputation are automated trading agent factors. Market mechanism, regulation and network externalities are external environment factors. Additionally, trust is a dealer factor. In this figure, each "big bubble" 
represents a collection of factors based on the same dimension, which includes main factors and their subfactors. In essence, those sub-factors are antecedent factors. Each "small bubble" represents a concept emergent from interviewees. In addition, each "arrowed line" shows an observed linkage based on different dimensions. The arrows point to several "dependent variables" or results, representing that object evaluation in this aspect need to consider the influence from "independent variables" or reasons.
More notably, it could be found from this figure that factors related to technology have multiple relations with other factors. It is shown that in ATS, the evaluation for a tradable object needs to be adjusted in this direction since it is influenced by intelligent factors from every aspect. Additionally, these interpretations to key statements and linkages among factors from interviewees are tentative findings requiring further investigation to determine more accurately.

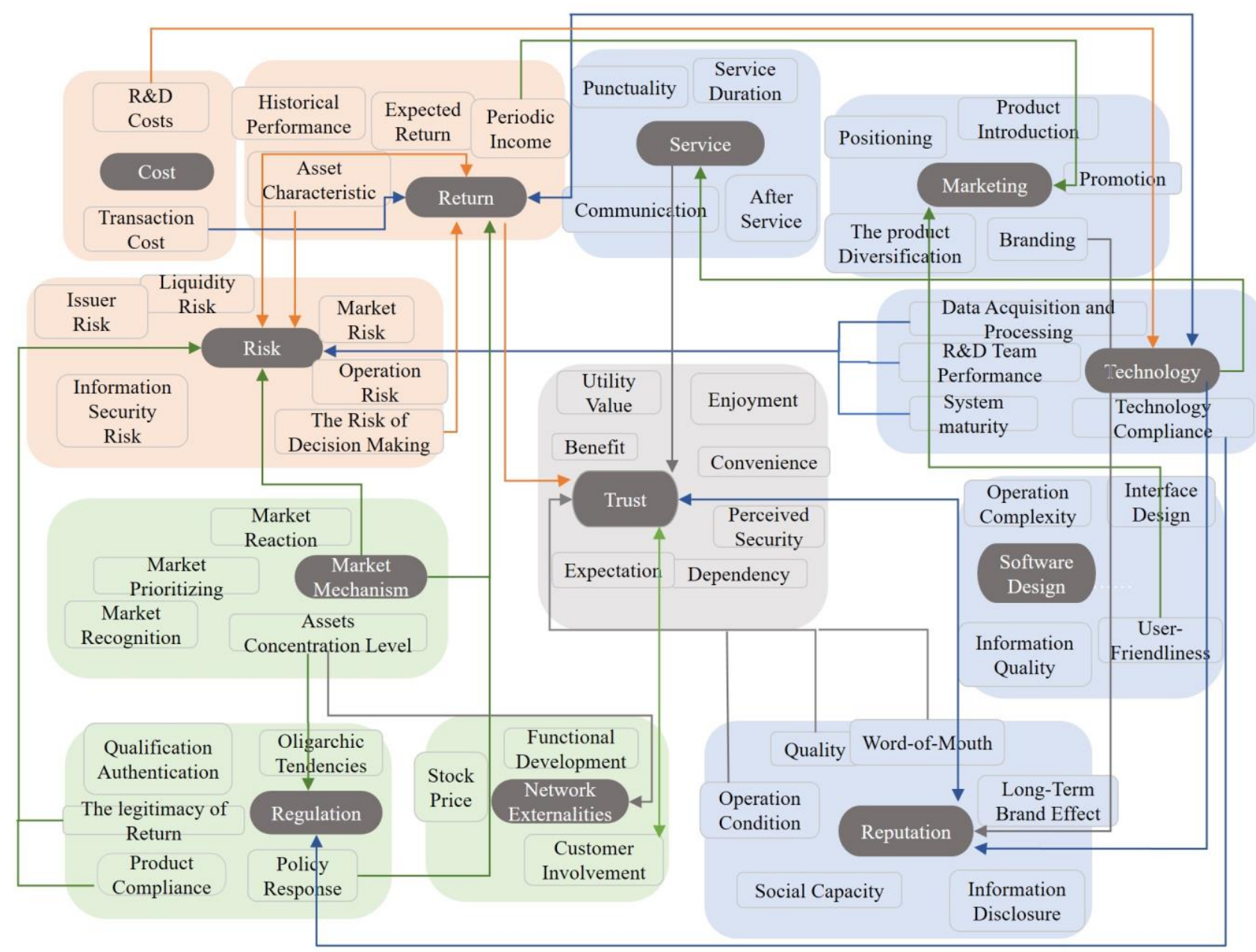

Figure 2. Integrated mapping of evaluation factors

\section{Conclusion and future research}

\subsection{Conclusion}

Smart city, as the precursor of intelligent economy, cannot be ignored in financial field. ATS, based on machine learning algorithms, emerges as times requires. To lay the foundation for helping develop the evaluation index system, we have studied the factors that affect objects in automated trading.
Due to the limitation of previous researches, we chose to conduct in-depth interviews rather than literature resource integration alone. We verified the eight factors found in literatures and succeeded in releasing four new factors form the interview. In addition, fifty-four sub-factors have been excavated with a deeper depth.

Theoretically, to fill the research gap, this study establishes an evaluation framework for the object of ATS. Also, this study digs out various main factors and sub-factors to augment the framework which can be the basis of evaluation index system. As a result, 
this research provides a new viewpoint for the evaluation of financial assets in the environment of automated trading and contributes to the research of ATS.

Practically, for the evaluation industry, this study is conducive to protecting the interests of stakeholders and promoting the standardization of market orders. For trading, this study can also promote its development to a certain extent.

Nonetheless, this research still has some limitations. The conclusion is only from the limited sample of the interview. Additionally, the study did not fully excavate the evaluation factors for the object of ATS, thus it cannot avoid the omission of the factors. There is also a limitation that the factors are mainly from interviewees. The correlation among factors has not been accurately verified. In addition, the factors only rely on qualitative methods rather than mixed method. Plus, ultimately it only forms a prototype without forming a complete index system. In the in-depth interview, we have collected twelve interview samples, although it involves investors from different industries, but the size and scope of the sample are both limited. We are looking forward to taking research on more stakeholders in the future.

\subsection{Future research}

Based on the preliminary framework that we have designed for the object evaluation, and a range of evaluation factors, we suggest designing the evaluation index system from four aspects in future work. These aspects are placed in the framework in Figure 3.

In the future, we plan to design a questionnaire to validate the linkages of factors proposed in this paper. We also expect to replicate a similar setting with comparable groups of stakeholders. Furthermore, we envision crawling pages of textual-news data and other related content. We propose to use big data mining approaches to leverage a large number of heterogeneous data [4] for validating what we proposed. Moreover, we will find out more evaluation factors to complete the relationship model and evaluation framework. Since we anticipate to aggregate findings across a wider range of instances, more effective sample data will be involved in the future work. In this study, we envision the future work of constructing a three-level-index evaluating model and calculate the corresponding objective weight of each indicator based on entropy.

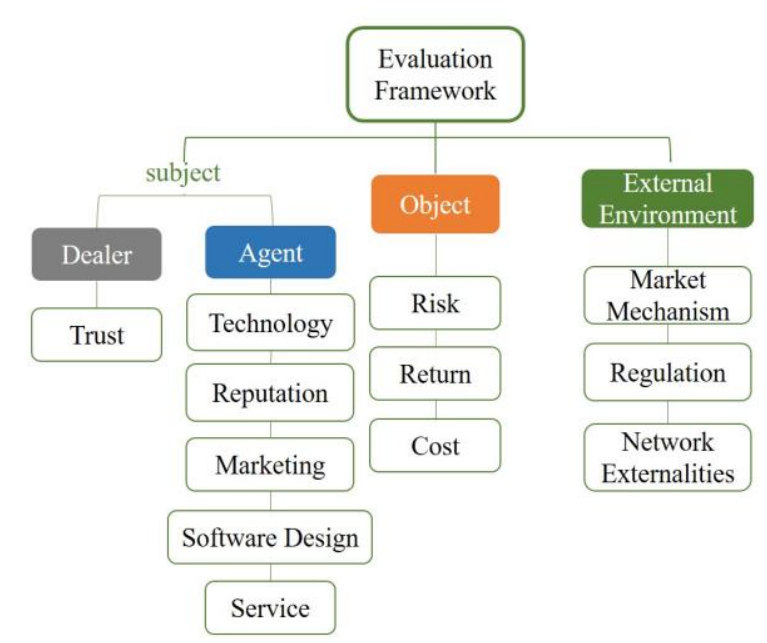

Figure 3. Evaluation framework for the object of ATS

\section{Acknowledgement}

The authors would like to thank the National Key R\&D Program of China (Grant No.2017YFB1400700) for providing funding for part of this research.

\section{References}

[1] M. Dohler, C. Ratti, J. Paraszczak, and G. Falconer, "Smart Cities", IEEE Communications Magazine, 2013, 51(6), pp.70-71.

[2] W. David, "Empowering Automated Trading in MultiAgent Environments", Computational Intelligence, 2010, 20(4), pp.562-583.

[3] A. Petropoulos, S.P. Chatzis, V. Siakoulis, and N. Vlachogiannakis, "A Stacked Generalization System for Automated Forex Portfolio Trading", Expert Systems with Applications, 2017, 90, pp. 290-302.

[4] T. Geva, and J. Zahavi, "Empirical Evaluation of an Automated Intraday Stock Recommendation System Incorporating both Market Data and Textual News", Decision Support Systems, 2014, 57(3), pp.212-223.

[5] S. Raudys, "Portfolio of Automated Trading Systems: Complexity and Learning Set Size Issues", IEEE Transactions on Neural Networks \& Learning Systems, 2013, 24(3), pp. 448-459.

[6] K. Izumi, F. Toriumi, and H. Matsui, "Evaluation of Automated-Trading Strategies Using an Artificial Market", Neurocomputing, 2009, 72(16), pp. 3469-3476.

[7] E.V. Bartkus, and A.P. Bartkute, "The Optimization and Evaluation of Investment Portfolio", Inzinerine Ekonomika-engineering Economics, 2013, 24(4), pp. 282290.

[8] F.D. Freitas, C.D. Freitas, and A.F. De Souza, "Intelligent Trading Architecture", Concurrency and Computation-practice \& Experience, 2016, 28(3), pp. 929943. 
[9] Y. Hu, K. Liu, X. Zhang, L. Su, E.W.T. Ngai, and M. Liu, "Application of Evolutionary Computation for Rule Discovery in Stock Algorithmic Trading: A Literature Review". Applied Soft Computing, 2015, 36, pp.534-551.

[10] P. Wilson, and J. Okunev, "Spectral Analysis of Real Estate and Financial Assets Markets". Journal of Property Investment \& Finance, 1997, 17(1), pp. 61-74.

[11] N. Ankarath, T.P. Ghosh, K.J. Mehta, and Y.A. Alkafaji, Understanding IFRS Fundamentals: International Financial Reporting Standards, John Wiley \& Sons, 2010.

[12] C. A. Carter, G. C. Rausser, and A. Schmitz, "Efficient Asset Portfolios and the Theory of Normal Backwardation", Journal of Political Economy, 1983, 91(2), pp. 319-331.

[13] A. Griffin, and A.L. Page, "PDMA Success Measurement Project: Recommended Measures for Product Development Success and Failure", Journal of Product Innovation Management, 1996, 13(6), pp. 478-496.

[14] E.F. Fama, and K.R. French. "Common Risk Factors in the Returns on Stocks and Bonds". Journal of Financial Economics, 1993, 33(1), pp.3-56.

[15] M. Cadoni, R. Melis, and A. Trudda, "Financial Crisis: A New Measure for Risk of Pension Fund Portfolios", PLOS ONE, 2015, 10(6), pp. 1-12.

[16] L. Guo, and D. Xia, "In Search of a Place in the Sun: The Shadow Banking System with Chinese Characteristics", European Business Organization Law Review, 2014, 15(3), pp. 387-418.

[17] E. Kim, and S. Tadisina, "A Model of Customers Trust in E-Businesses: Micro-Level Inter-Party Trust Formation", Data Processor for Better Business Education, 2007, 48(1), pp. 88-104.

[18] S. Kim, W. Ha, J. Seo, S. Han, and M. Kim, “A Method of Evaluating Trust and Reputation for Online Transaction", Computing \& Informatics, 2015, 33(5), pp.1095-1115.

[19] Y.J. Kim, B.C. Cin, K. Cho, and J. Yi, "Introduction: Technology, Finance, and Trade in Emerging Markets", Emerging Markets Finance \& Trade, 2015, 51(5), 945-946.

[20] H.E. McKibben, "Dangerous Trade Arms Exports, Human Rights, and International Reputation", Perspectives on Politics, 2016, 14(2), pp.595-596.

[21] D.P. Giulia, G. Massimo, P. Manuela and V. Fabiola. "Regime Shifts in Excess Stock Return Predictability: An Out-of-Sample Portfolio Analysis", The Journal of Portfolio Management Winter, 2018, 44 (3), pp. 10-24

[22] H.J. Lee, and H. Choe. "Individuals' Return Predictability in Market and Limit Trades", Journal of Financial Studies, 2014, 43(1), pp. 59-88.

[23] Y.V. Kostynets, "Model of Intermediary Services Market as a Marketing System", Actual Problems of Economics, 2011, 120, pp. 119-123.

[24] M.B. Fox, L.R. Glosten, and G.V. Rauterberg, "Stock Market Manipulation and Its Regulation", Yale Journal on Regulation, 2018, 35(1), pp.67-126.

[25] A.M. Corcoran, and J.C. Lawton, "Regulatory Oversight and Automated Trading Design: Elements of Consideration", Journal of Futures Markets, 2010, 13(2), pp.213-222.

[26] M. Katz, and C. Shapiro, "Network Externalities, Competition, and Compatibility", The American Economic Review, 1985, 75(3), pp.424-440.
[27] T. Kikuchi, and C. Kobayashi. "Network Externalities, Competition, and Trade: East Asian Perspectives", Korea \& the World Economy, 2006, 7(1), pp. 119-134.

[28] D. Bardey, H. Cremer, and J.M. Lozachmeur, "Competition in Two-Sided Markets with Common Network Externalities", Review of Industrial Organization, 2014, 44(4), pp.327-345.

[29] X. Cheng, S. Fu, and D. Druckenmiller. "Trust Development in Globally Distributed Collaboration: A Case of US and Chinese Mixed Teams", Journal of Management Information Systems, 2017, 33(4), 978-1007.

[30] J.C. Jones, and D.G. Thornley, "Conference on Design Methods", Papers Presented at the Conference on Systematic and Intuitive Methods in Engineering, Industrial Design, Architecture and Communication, London, 1963.

[31] R. Winter, "Design Science Research in Europe", European Journal of Information Systems, 2008, 17(5), pp. 470-475.

[32] K. Peffers, T. Tuunanen, M. Rothenberger, and S. Chatterjee, "A Design Science Research Methodology for Information Systems Research", Journal of Management Information Systems, 2007, 24(3), pp. 45-77.

[33] S. Cavalieri, P. Maccarrone, and R. Pinto, "Parametric vs. Neural Network Models for the Estimation of Production Costs: A Case Study in the Automotive Industry", International Journal of Production Economics, 2004, 91(2), 165-177.

[34] J. Iivari, "Distinguishing and Contrasting Two Strategies for Design Science Research", European Journal of Information Systems, 2015, 24(1), pp. 107-115.

[35] M. Chau, and J. Xu, "Business Intelligence in Blogs: Understanding Consumer Interactions and Communities Business Intelligence in Blogs: Understanding Consumer Interactions and Communities Introduction", MIS Quarterly, 2012, 36(4), pp. 1189-1216.

[36] J.A. Teresi, R.R. Golden and B.J. Gurland, "Concurrent and Predictive Validity of Indicator Scales Developed for the Comprehensive Assessment and Referral Evaluation Interview Schedule", Journal of Gerontology, 1984, 39(2), pp. 158.

[37] T.W. Andreassen, R.D.V. Oest, and L. Lervik-Olsen, "Customer Inconvenience and Price Compensation: A Multiperiod Approach to Labor-automation Trade-offs in Services", Journal of Service Research, 2017, 21(2), pp.173-183.

[38] N. Mizik, and R. Jacobson, "Financial Markets Research in Marketing", Journal of Marketing Research, 2009, 46(3), pp. 320-324. 